\title{
Isolation, purification, and characterization of xylanase produced by three species of bacillus under submerged fermentation conditions
}

\author{
Bhuvnesh Yadav ${ }^{*}$ and Khushboo Chandra \\ Faculty of Allied Health Sciences, SGT University, Gurgaon-122505 (Haryana), INDIA \\ *Corresponding author. E-mail. bhuvneshyadav@gmail.com
}

Received: Septemer 22, 2015; Revised received: April 27, 2015; Accepted: July 11, 2016

\begin{abstract}
This study focuses on the screening and identification of bacteria, which can produce alkaline xylanase at alkaline $\mathrm{pH}$ and high temperature. Bacterial isolates from enriched decaying soil, capable of hydrolyzing xylan were screened. Selected and purified 13 bacterial colonies (Bacilli and Kurthia) grown on xylan- nutrient agar slants, were activated and transferred into the fermentation medium. Three highest xylanase producing isolates (Bacillus badius, Kurthia gibsonii, Bacillus circulans) were selected for further studies and the xylanase produced by them were screened for their kinetic properties. The optimum temperature for the activity of the xylanase from Isolates $A$ was $50^{\circ} \mathrm{C}$; and for Isolate $\mathrm{B}$ was $40^{\circ} \mathrm{C}$, while that of Isolate $\mathrm{C}$ was $30^{\circ} \mathrm{C}$. The optimum $\mathrm{pH}$ value for the xylanase from isolate $A$ and $B$ was 9.0. In addition, the xylanase was also capable of producing high-quality xylo-oligosaccharides, which indicated its application potential not only in pulp bio-bleaching processes but also in the nutraceutical industry.
\end{abstract}

Keywords: Bacillus badius, Kurthia gibsonii, Submerged fermentation, Xylanase

\section{INTRODUCTION}

The uses of enzymes (microbial origin) in medicine and the industry are remarkably diverse. The enzymes are responsible for the hydrolysis of plant polysaccharides, including cellulose, lipid, nucleic acid, starch and cell wall components (Kalia et al., 2000). The high yield of these enzymes in cultural fluids and their robust properties, especially their tolerance to extremes of $\mathrm{pH}$ and temperature, led to their application in various industries particularly in starch and food processing industries, where they have replaced several unsatisfactory chemical processes and in household laundry detergents (Viikari et al., 1994; Flores et al., 1997).

Commercial production of these microbial enzymes involves use of a wide range of species of bacteria, fungi and yeasts (Archana and Satyanarayana, 1997). The microorganisms are preferred for the production of industrially important enzymes as these have higher growth and multiplication rate; can be easily modified genetically to increase the production of particular type of enzyme due to the following reasons: growth is high in bacteria, can produce enzymes on extreme conditions of environment such as high temperature and $\mathrm{pH}$ and have simple nutritional requirements (Gupta, 2008; Srinivasan, 1999)

The main purpose of isolating the thermophillic and alkalophilic bacteria is to produce enzymes which can be used in new processes and improve existing processes such as single step conversion of starch to glucose- maltose syrup using the glucosidase from Thermococcus hydrothermalis.
Xylanases are a group of hydrolytic enzymes that act on xylan which is second most abundant polysaccharide in nature (Gupta and Kar, 2008). Xylanases are of industrial importance, which can be used in paper manufacturing to bleach paper pulp, increasing brightness of pulp and improving the digestibility of animal feed and for clarification of fruit juices (Srinivasan and Rele, 1999; Viikari et al., 1990). Applications of xylanase avoid the use of chemicals that are expensive and cause pollution (Chidi et al., 2008). Microorganisms are the rich sources of xylanases, produced by diverse genera and species of bacteria, actinomycetes, and fungi. Several species of Bacillus and filamentous fungi secrete high amounts of extracellular xylanases (Gupta et al., 2001; Azeri et al., 2010; Sudan and Bajaj, 2007). Production of xylanase can be carried out using either submerged fermentation $(\mathrm{SmF})$ or solid state fermentation. Submerged fermentation systems are extensively used for the production of costly material and for the study of biochemical and physiochemical aspects of the synthesis of microbial metabolites. The objective of the study was isolation, physiological and biochemical screening and the time profile of alkaline (xylanase) enzyme production under submerged fermentation conditions.

\section{MATERIALS AND METHODS}

Isolation of alkalophilic bacteria from soil sample: Soil samples rich in organic matter (collected from different sources) were dried in an oven at $37^{\circ} \mathrm{C}$ for 24 hours. One gram of soil sample was added to $10 \mathrm{ml}$ of 
normal saline $(0.85 \% \mathrm{NaCl})$ solution. Samples were vortexed for two minutes followed by the contents to settle down. One $\mathrm{ml}$ of supernatant was taken and added to $100 \mathrm{ml}$ of enrichment (nutrient agar and actinomycetes agar) mediums.

Isolation of the pure culture by gram staining and spore staining: The isolated colonies on nutrient agar and actinomycetes isolation agar plates were studied for purity by Gram's staining and Spore staining (Bergey et al., 1994). The smears were observed under oil emulsion. Plate assay for enzyme production: Prominent selected isolate was identified on the basis of morphological, cultural, biochemical properties. Single colonies of the selected isolates grown on xylan nutrient agar plate were observed for morphological characters in terms of margin, colour, surface, opacity and shape. Pure cultures were streaked on basal xylan $(0.25 \%)$ agar medium to check the production of xylanase enzymes. Bacterial cultures were incubated at $37^{\circ} \mathrm{C}$ for 48 hours. The plates were stained with Congo red for 15 minutes and then destained with $\mathrm{NaCl}(1 \mathrm{ml})$ solution. The yellow zone round the colony surrounded by red background indicated the presence of xylanase (Miller, 1959).

Biochemical identification of the isolates: Biochemical testing (Carbohydrate, Citrate utilization, Catalase, Indole, Nitrate reduction, Voges- proskauer and Mac Conkey agar test) was done to identify and characterize the bacterial strains (MacFaddin, 2000).

Xylanase production under submerged fermentation: The selected strain was further tested for their abilities to produce extracellular xylanase under submerged fermentation. The bacterial isolates were cultured on two different basal media for production of xylanase i.e. wheat bran and corncob pulp mediums were used as substrates. The enrichment was done by inoculation in Peptone water and the xylanase production was monitored periodically after every 24 hours. The assay was performed using a suspension of Birchwood xylan as substrate. The reducing sugars were estimated by DNS method (Miller, 1959).

For identification of the isolates, the results of biochemical tests, plate assays and colony morphology were compared with identified ones from Bergey's Manual of Systematic Bacteriology (Sneath, 1986).

Protein measurement: Protein concentration was measured by Lowry's method (Lowry et al., 1951) using Bovine serum albumin.

\section{RESULTS AND DISCUSSION}

Isolation of xylose producing strains and screening for xylanase producing strains: Of the 13 bacterial strains isolated from soil collected at selected study site, three (Isolate A,B,C) formed clear halos around their colonies on xylan agar plates and were picked up for further studies. The strain that showed zone of clearance around the colony proved its xylanolytic ability. All the three isolates were Gram positive as indicated by Gram staining and Mac Conkey test but the spore formation was observed only in isolate A and C. Isolate A formed a creamish white colony and diffused morphology with serrate margin. The colonies of Isolate B were with round morphology and elevated margins. Whereas the Isolate $\mathrm{C}$ was identified with small rounded creamish white bacteria with round and elevated margins. Biochemical tests were carried out to confirm the genus of the isolate and to identify the species. The isolates $\mathrm{B}$ and $\mathrm{C}$ were good catalase producers in comparison with Isolate A. All the three strains showed good growth under aerobic condition but did not grow under anaerobic condition. This indicated that the strains are strict aerobes. The isolates did not utilize citrate as the carbon source, also did not utilize tryptophan. Any one of isolate could not produce indole, did not produce starch hydrolysing enzyme and did not produce nitrate (Table 1).

Identification of the selected isolate: The morphological, physiological and biochemical characters of the isolates were compared to the identified bacteria from Bergey's Manual of Systematic Bacteriology (Sneath, 1986). It was observed that the characters of the Isolate A based on Gram staining; its morphology, aerobic nature, biochemical characters and its ability to grow at temperature $50^{\circ} \mathrm{C}$ and $\mathrm{pH}>7$ were most closely related to the species Bacillus badius.

Likewise, the Isolate B with morphological characters (short Gram positive aerobic rod, yellow colony without spore formation) and ability to lipase digestion and casein hydrolysis with growth temperature $40^{\circ} \mathrm{C}$ was identified as Murtha gibsonia.

In similar manner, as the Isolate $\mathrm{C}$ had the ability to grow at $\mathrm{pH}>7$ and at temperatures $>30^{\circ} \mathrm{C}$ and other characters were similar to Bacillus circulans and it was identified as $B$. circulans.

Optimization of xylanase production in SmF: When the strain was grown in two different mediums i.e. wheat bran and pulp for 48 hours of incubation at $\mathrm{pH}$ 9.0 and $50^{\circ} \mathrm{C}$, maximum xylanase production was observed after 48 hours in pulp enriched medium (45IU) whereas; maximum production of 35.8 IU was observed after 24 hours in wheat bran medium by Isolate A. A similar pattern was observed in case of Isolate B (Figure 1). Several workers also reported the suitability of wheat bran for xylanase production in solid state fermentation (Kamble and Jadhav, 2012). But our study suggests that corncob is the better source for production of xylanase enzyme.

Effect of temperature on xylanase production: For xylanase from both the Bacillus sp., activity was observed to be gradually increasing with the increasing temperature and found significantly declined at $80^{\circ} \mathrm{C}$. $50^{\circ} \mathrm{C}$ was found to be the most favourable for enzyme activity. Stability of the enzyme was the most important factor in studying characteristics. It was found that these xylanases were most active at $50^{\circ} \mathrm{C}$ to $60^{\circ} \mathrm{C}$. 
Bhuvnesh Yadav and Khushboo Chandra / J. Appl. \& Nat. Sci. 8 (3):1210 - 1213 (2016)

Table1. Morphological and biochemical characteristics of the selected bacterial colonies.

\begin{tabular}{|c|c|c|c|}
\hline Test & Isolate A & Isolate B & Isolate $C$ \\
\hline Gram staining & + & + & + \\
\hline Spore staining & + & - & - \\
\hline \multicolumn{4}{|l|}{ Colony } \\
\hline Morphology & Diffused & Round & Small round \\
\hline Margin & Serrate & Round & Round \\
\hline Elevation & Flat & Elevated & Elevated \\
\hline Colour & Creamish White & Yellow & Creamish white \\
\hline Xylanase & + & + & - \\
\hline Tannase & - & - & - \\
\hline Lipase & - & + & - \\
\hline Amylase & - & - & - \\
\hline Cellulase & - & - & - \\
\hline Protease & + & + & - \\
\hline \multicolumn{4}{|l|}{ Carbohydrate test } \\
\hline Starch & - & + & - \\
\hline Sucrose & - & + & - \\
\hline Maltose & - & + & - \\
\hline Lactose & - & - & + \\
\hline Dextrose & - & + & - \\
\hline Catalase & + & +++ & ++ \\
\hline Citrate Utilization & - & - & - \\
\hline Nitrate reduction & - & - & + \\
\hline Indole test & - & - & - \\
\hline MR-VP test & - & - & - \\
\hline Mac Conkey test & + & + & + \\
\hline Temp. & $50^{\circ} \mathrm{C}$ & $40^{\circ} \mathrm{C}$ & $30^{\circ} \mathrm{C}$ \\
\hline pH & $>7$ & $>7$ & $>7$ \\
\hline
\end{tabular}

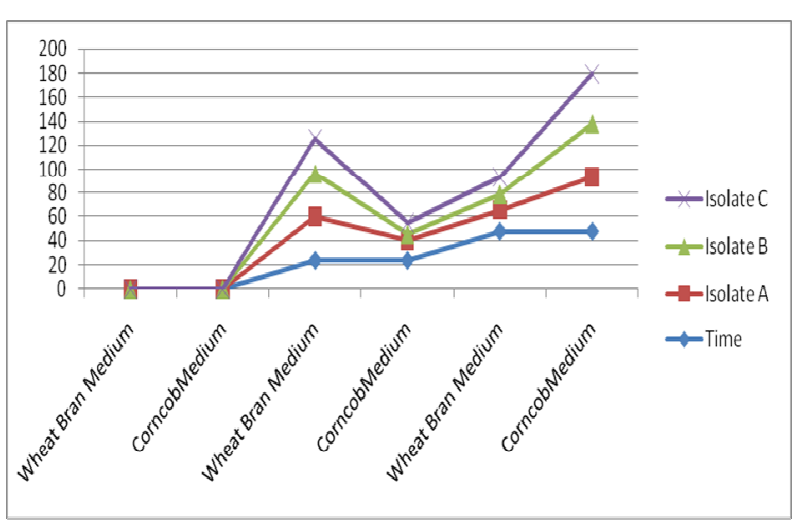

Fig. 1. Comparative analysis of xylanase production in two different mediums at different temperatures.

Kang et al. (Kang et al., 1996) purified two xylanases which gave the highest activity at $50^{\circ} \mathrm{C}$ and showed relatively high stability at $50^{\circ} \mathrm{C}$ temperature. The similar observations were reported by Mahilrajan et al. also (Mahilrajan et al., 2012). The bacterial strains from this study were also followed the similar pattern and the enzyme activity was prominent at and above $50^{\circ} \mathrm{C}$. It has been previously reported that there are large number of alkali stable xylanase producing bacteria $(B$. subtilis, B. halodurans PPKS2, Bacillus AP4, AS11 and F) (Annamalai et al., 2009; Prakash et al., 2009; Dholpuria et al., 2015). The purified xylanase also was capable of producing high-quality xylooligosaccharides, indicating its application potential not only in pulp bio-bleaching processes but also in the nutraceutical industry. B. badius and $K$. gibsonii produced thermoalkalophilic cellulose-free xylanase in greater amount when grown in submerged conditions using cheap and abundantly available agro-residual substrate like corncob and wheat bran. Hence, it can be used for large-scale production of xylanase using such agro-residual substrates.

\section{Conclusion}

Three high xylanase producing bacterial strains identified and isolated were $B$. badius, $M$. gibsonii and $B$. circulans. The ambient temperature for growth was $50^{\circ} \mathrm{C}$ for B. badius, $40^{\circ} \mathrm{C}$ for $\mathrm{M}$. gibsonia and $30^{\circ} \mathrm{C}$ for $B$. circulans and the optimal $\mathrm{pH}$ was $>7$. The production of xylanase was observed in wheat bran and pulp enriched medium and the temperature for growth was $50^{\circ} \mathrm{C}$. For xylanase from both the Bacillus sp., activity was observed to be gradually increasing with the increasing temperature and found significantly declined at $80^{\circ} \mathrm{C} .50^{\circ} \mathrm{C}$ was found to be the most favourable for enzyme activity. Stability of the enzyme was the most important factor in studying characteristics. It was found that these xylanases were most active at $50^{\circ} \mathrm{C}$ to $60^{\circ} \mathrm{C}$. B. badius and $K$. gibsonii produced thermoalkalophilic cellulose-free xylanase in greater amount when grown in submerged conditions using cheap and abundantly available agro-residual substrate like corncob and wheat bran. 


\section{REFERENCES}

Annamalai, N., Tharasai, R., Jayalakshmi, S. and Balasubramanian, T. (2009). Thermostable and alkaline tolerant xylanase production by Bacillus subtilis isolated from marine environment. Ind. J. Biotech. 8 : 291-292.

Archana, A. and Satyanarayana, T. (1997). Xylanase production by thermophilic Bacillus licheniformis A99 in solid -state fermentation. Enzyme and Microbial Tech. 21 (1) : 12-17.

Azeri, C., Tamer A.U. and Oskay M. (2010).Thermoactive cellulase-free xylanase production from alkaliphilic Bacillus strains using various agro-residues and their potential in biobleaching of kraft pulp. Afr. J. Biotech. 9 (1) : 63-72.

Bergey, D.H., Holt, J.G., Krieg, N.R. and Sneath, P.H.A. (1994). Bergey's Manual of Determinative Bacteriology (9th ed.).

Chidi, S.B., Godana, B., Ncube, I., Van Rensburg, E.J., Cronshaw, A. and Abotsi, E.K. (2008). Production, purification and characterization of cellulase-free xylanase from Aspergillus terreus UL 4209. Afr. J. Biotech. 7(21) : 3939-3948.

Flores, M.E., P'erez, R. and Huitr, C. (1997). $\beta$-Xylosidase and xylanase characterization and production by streptomyces sp. CH-M-1035. Letters in Appl. Microbio. 24 (5) : 410-416.

Gupta, S., Bhushan, B., Hoondal G.S. and Kuhad, R.C. (2001). Improved xylanase production from a haloalkalophilic Staphylococcus sp SG-13 using inexpensive agricultural residues. World J Microbio. and Biotech. 17 : 5-8.

Gupta, U. and Kar, R. (2008). Optimization and scale-up of cellulase free endo xylanase production by solid state fermentation on corncob and by immobilized cells of a thermotolerant bacterial isolate. Jordan J Bio. Sci., 1: 129-134.

Kalia, V.C., Raizada, N. and Sonakya, V. (2000). Bioplastics. J Sci. and Indust. Res. 59:433-445.

Kamble, R.D. and Jadhav, A.R. (2012). Isolation, purification, and characterization of xylanase produced by a new species of Bacillus in solid state fermentation. Int.
J Microbio., Article ID 683193, pp. 8.

Kang, M.K., Maeng P.J. and Rhee, Y.H. (1996). Purification and characterization of two xylanases from alkaliphilic Cephalosporium sp. strain RYM-202. Appl. and Environ. Microbio. 62 (9) : 3480-3482.

Lowry, O.H., Rosebrough, N.J., Farr, A.L. and Randall, R.J. (1951). Protein measured with the Folin phenol reagent. J Bio. Chem., 193: 265-275.

MacFaddin, J.F. (2000). Biochemical tests for identification of medical bacteria, 3rd ed. Lippincott Williams \& Wilkins, Philadelphia, PA

Mahilrajan, S., Balakumar, S. and Arasaratnam, V. (2012). Screening and identification of a thermophilic and alkalophilic bacterium producing xylanase. Adv. Appl. Sci. Res. 3 (1) : 242-250.

Miller G.L. (1959). Use of dinitrosalicylic acid reagent for the determination of reducing sugars. Ana. Chem., 31 : 538-542.

Prakash, S., Veeranagouda, Y., Kyoung, I. and Sreeramulu, K. (2009). Xylanase production using inexpensive agricultural wastes and its partial characterization from a halophilic Chromohalobacter sp TPSV101. World J Micro. Biotech. $25: 197-204$.

Sneath, P.H.A. (1986). Endospore-forming gram-positive rods and cocci, Bergey's manual of systematic bacteriology. The William and Wilkins Co., Baltimore, 1104-1139.

Srinivasan, M.C. and Rele, M.V. (1999). Microbial xylanases for paper industry. Cur. Sci., 77 (1) : 137-142.

Sudan R. and Bajaj, B.K. (2007). Production and Biochemical characterization of xylanases from an alkalitolerant novel sp Aspergillus niveus RS2. World J Micro. and Biotech. 23(4): 491-500.

Viikari, V., Kantelinen, J. and Linko, M. (1994). Xylanases in bleaching: from an idea to the industry FEMS. $M i$ crobio. Rev. $13: 335-350$.

Viikari, L., Kantelinen, A., Poutanen, K. and Ranua, M. (1990). Characterization of pulps treated with hemicellulolytic enzymes prior to bleaching in Biotechnology in Pulp and Paper Manufacture, T. K. Kirk and H. M. Chang, Eds.,145-151, Butterworth-Heinemann, Stoneham, Mass, USA. 